\title{
ПОЛИМЕРНЫЕ ГЕЛИ ДЛЯ УПРАВЛЕНИЯ ВОДООБЕСПЕЧЕННОСТЬЮ ПШЕНИЦЫ (Triticum aestivum L.) В РАЗНЫХ ЭКОЛОГИЧЕСКИХ УСЛОВИЯХ
}

\author{
Т.Н. ДАНИЛОВАํ, Л.К. ТАБЫНБАЕВА²
}

В последние годы в связи с наблюдаемыми изменениями климата и ухудшением водообеспеченности посевов особое внимание проявляется к разработке влагонабухающих полимеров и оптимизации режимов их применения. В представленной работе проведено испытание отечественного гидрогеля Ритин-10 (ООО «РИТЭК-ЭНПЦ», г. Электрогорск, Россия) в сравнении с полимером Aquasorb («SNF s.a.s.», Франция) в условиях России и Казахстана на посевах яровой и озимой пшеницы. Влияние гидрогеля Ритин-10 на водообеспечение растений яровой пшеницы (сорт Эстер) исследовали в полевом эксперименте (2011 год) при внесении в почву из расчета 400 кг/га в сочетании с разными дозами азотных удобрений $\left(\mathrm{N}_{60}, \mathbf{N}_{90}\right.$ и $\left.\mathrm{N}_{120}\right)$. Анализ влажности почвы в разные периоды вегетации показал, что гидрогель Ритин-10 достоверно (р $<0,05)$ повышал влажность почвы по сравнению с контролем. Содержание влаги в вариантах с азотными удобрениями и с гидрогелем варьировало от 19,33 до 31,60\%, в вариантах с азотными удобрениями без гидрогеля - от 13,14 до $17,40 \%$ при показателях в контроле в период вегетации от 11,36 до 17,10\%. Запасы продуктивной влаги при внесении Aquasorb в период кущения озимой пшеницы были выше на 10,30-19,00\% по сравнению с контрольным фоном. Так, при применении азотной подкормки в дозе $\mathrm{N}_{45}$ этот показатель составил от 23,90 до 31,00\%. Внесение гидрогеля Ритин-10 привело к достоверному (p < 0,001) увеличению урожайности зерна яровой пшеницы. Урожайность в вариантах с применением гидрогеля и азотных удобрений колебалась от 33,23 до 35,70 ц/га. Самую высокую продуктивность (урожайность зерна на 10 ц/га больше, чем на контроле) получили при сочетании $\mathrm{N}_{120}+$ Ритин-10. В эксперименте с применением Aquasorb без удобрений и с удобрением урожайность озимой пшеницы (сорт Стекловидная 24) колебалась в пределах 27,00-35,70 ц/га. Результаты проведенных исследований показали, что гидрогель отечественного производства Ритин-10, как и суперабсорбент Aquasorb, эффективен при управлении водообеспеченностью сельскохозяйственных культур.

Ключевые слова: Triticum aestivum L.), яровая пшеница, озимая пшеница, влагопоглощающие полимеры, почвенная влага, корневая система, водообеспеченность, урожайность.

Применение влагонабухающих полимеров рассматривается как один из инновационных нетрадиционных подходов в современных агротехнологиях. Сильнонабухающие (влагонабухающие) полимерные гидрогели представляют собой редкосшитый гидрофильный полимерный материал акрилатной природы. Они многократно увеличиваются в объеме при набухании, обладают высокой водосорбирующей способностью, при этом стабильны при многократных циклах иссушения и набухания (1). При внесении в почвенный корнеобитаемый слой частицы геля располагаются в межагрегатном пространстве и при поступлении влаги набухают, обеспечивая прирост влажности по сравнению с показателями в необработанной почве. В результате оптимизируется водный баланс и создаются условия влагообеспеченности, благоприятные для роста и развития растений. Основная часть воды в гидрогеле имеет потенциал 4,2 > pF > 2,0 (значения, характеризующие биологически доступную влагу) и эффективно используется растениями. При высыхании абсорбент принимает первоначальную кристаллическую форму и готов к новому циклу при последующем увлажнении. Цикличность поглощения и отдачи влаги на протяжении нескольких лет присуща гидрогелям полиакриламидного типа, поэтому их применение наиболее целесообразно при проведении сельскохозяйственных мероприятий $(2,3)$.

При использовании гидрогелей вода и удобрения (в виде почвенного раствора) запасаются в зоне корневой системы растений и питают их. Многие отмечают (4-6), что гидрогели увеличивают количество доступной влаги в корневой зоне, подразумевая при этом более длительные интервалы меж- 
ду поливами. Влагоемкость зависит от текстуры почвы, типа гидрогеля и размера частиц (порошок или гранулы), $\mathrm{pH}$ почвенного раствора.

Результаты исследований отечественных ученых $(7,8)$ показали, что гидрогели - одно из наиболее мощных синтетических средств управления гидрофизическими свойствами и водным режимом почв. Дозы отечественных полимерных гелей 0,10-0,25 \% от массы почвы снижают ее плотность в 1,2-1,5 раза, что создает дополнительную пористость и повышает полную влагоемкость до 30-40 \% против 23-25 \%. В зарубежных публикациях сообщалось (9-11), что обработка почвенных субстратов синтетическими гидрофильными гелями при дозах препаратов от 0,1-0,3 до 0,5 \% от массы почвы способствовала лучшему прорастанию семян, стимулировала рост культур и повышала их урожайность на 30-40 \%. Установлено (12), что Aquasorb («SNF s.a.s.», Франция) за 20 мин поглощает $50 \%$ воды, за 120 мин - $100 \%$. Объемы адсорбции варьируют от 30 до 500 л на 1 кг сухого полимера. Такая водопоглощающая способность может эффективно поддерживаться в течение 4-5 лет, при этом водообмен между почвой и полимером носит обратимый характер.

Гидрогели применяются в качестве дополнительных добавок при выращивании растений в регионах, где водные ресурсы служат ограничивающим фактором. Использование суперпоглощающего полимера устраняет последствия засухи и способствует развитию у растений засухоустойчивости (13). Использование гидрогелей значительно уменьшает число поливов, особенно для почв с грубой структурой $(14,15)$.

Ритин-10 представляет собой сшитый сополимер полиакриламида, синтезирован посредством внешнего воздействия ионизирующего излучения (технология научно-технического полигона ПАО «ЛУКОЙЛ» - ООО «РИТЭК-ЭНПЦ», Россия) и в основном применяется в нефтедобывающей промышленности для повышения нефтеотдачи пластов. Химический состав гидрогеля: $\mathrm{C}-11 \% ; \mathrm{N}-4,7 \% ; \mathrm{O}_{2}-16,4 \% ; \mathrm{Cl}-1,01 \%$; $27,05 \% ; \mathrm{Na}-36,98 \%$. Также находит применение в растениеводстве: 1 г гидрогеля удерживает около 300 мл воды, доступность влаги для растений - $95 \%$; производительность в почве - до 5 лет (16). Сельскохозяйственные испытания Ритина-10 начаты нами в 2008 году (17). Результаты полевых опытов по выращиванию озимой пшеницы по полупару показали эффективность этого гидрогеля в Ставропольском крае (18).

В представленной работе проведено испытание отечественного гидрогеля Ритин-10 (ООО «РИТЭК-ЭНПЦ», Россия), полученного из отходов нефтяной промышленности, в сравнении с известным водосорбирующим полимером Aquasorb («SNF s.a.s.», Франция) в полевых опытах в условиях России и Казахстана.

Цель работы заключалась в сопоставлении эффективности гидрогеля российского производства (Ритин-10) по влиянию на водообеспечение растений пшеницы в зависимости от азотного питания и суперабсорбента Aquasorb при применении на почвах разного типа.

Методика. Действие гидрогеля Ритин-10 (ООО «РИТЭК-ЭНПЦ», Россия) на водообеспечение яровой пшеницы (Triticum aestivum L.) сорта Эстер (предшественник - картофель сорта Скарб) изучали в технологическом цикле посев-товарная продукция в полевом эксперименте (ФГБНУ Агрофизический институт, полевой стационар Меньковского филиала, Ленинградская обл., 2011 год) на дерново-подзолистых легкосуглинистых почвах на разных фонах азотного питания. Агрохимическое обследование опытного участка выполняли согласно методике полевого опыта (19). Образцы почвы отбирались почвенным буром на глубину пахотного слоя, 
определяли кислотность (рН солевой вытяжки) потенциометрическим методом согласно ГОСТ 26483-85, содержание аммонийного азота $\mathrm{N}_{-} \mathrm{NH}_{4}-$ по ГОСТ 26489-85, нитратного азота - по ГОСТ 26951-86, подвижных форм фосфора и калия - по Кирсанову (ГОСТ 26207-91), влажность - по ГОСТ 28268-89. Гидрогель вносился в корнеобитаемый слой (5-7 см) в предпосевной период в дозе 400 кг/га. Размер делянок -80 м $^{2}(8 \times 10$ м), повторность 2-кратная. Тестировали сочетания гидрогеля (400 кг/га) с азотными удобрениями в дозах $\mathrm{N}_{60}, \mathrm{~N}_{90}$ или $\mathrm{N}_{120}$; контролями служили вариант без гидрогеля и азотных удобрений и вариант с гидрогелем (400 кг/га) без азотных удобрений. В вегетационный период проводили биометрические и фенологические наблюдения по фазам развития растений и отбирали образцы почвы для определения влажности.

Влияние абсорбента Aquasorb («SNF s.a.s.», Франция) на водообеспечение озимой пшеницы сорта Стекловидная 24 исследовали в стационарных полевых опытах (Казахский НИИ земледелия и растениеводства, 2015-2016 годы) на светло-каштановой легкосуглинистой почве. Тестировали две дозы абсорбента (20 и 40 кг/га) и их сочетание с азотной подкормкой $\left(\mathrm{N}_{45}\right)$; контроль - вариант без абсорбента и азотных удорений).

Полевые и лабораторные наблюдения (анализы) и учеты проводили по методике полевого опыта (19).

Для статистической обработки данных использовали пакет программ Statistics 5.0 («StatSoft, Inc.», США). Вычисляли значения средних $(M)$ и стандартных отклонений $( \pm \mathrm{SD})$. Достоверность различий средних оценивали с помощью двухфакторного дисперсионного анализа (ANOVA), различия считали статистически значимыми при $\mathrm{p} \leq 0.05$.

Результаты. В Меньковском филиале распространены дерновослабо- и дерново-средне-подзолистые почвы. Среди этих почв преобладают легко-средне-суглинистые и супесчаные на морене. Гранулометрический состав дерново-подзолистой легкосуглинистой почвы: физической глины $-27,96 \%$, крупной пыли $-22,4 \%$, ила $-6,11 \%$ (К.Г. Моисеев. База данных почвенного покрова Меньковского филиала ГНУ АФИ Россельхозакадемии, структура почвенного покрова, геоморфологическое строение, физические и геохимические свойства почв, 2013). Результаты выполненного нами агрохимического обследования опытного участка показали, что содержание общего азота составляет 0,37 \% при высокой обеспеченности фосфором и калием: количество $\mathrm{P}_{2} \mathrm{O}_{5}-724,7$ мг/кг, $\mathrm{K}_{2} \mathrm{O}-$ 280,9 мг/кг (по Кирсанову). По величине $\mathrm{pH}_{\mathrm{KCl}} 5,8$ почва относится к слабокислым или близким к нейтральным.

В условиях Ленинградской области внесение гидрогеля в предпосевной период хорошо сказалось на развитии корневой системы яровой пшеницы в фазу кущения, большая часть корней (рис. 1, справа) находилась в зоне внесения гидрогеля. Эффект гидрогеля был наибольшим в период от фазы кущения (в Северо-Западной зоне России конец маяначало июня считается засушливым периодом) до фазы цветения и особенно в фазу выхода в трубку. Это самые критические фазы развития яровой пшеницы, когда происходит формирование урожая, и недостаток влаги в эти периоды сильно влияет на урожайность культуры (20).

Наличие гидрогеля в корнеобитаемом слое существенно сказывалось на формировании биомассы. В период вегетации происходил усиленный рост растений при хорошей густоте стояния. Фенологические и биометрические наблюдения показали, что биомасса растений (относительно таковой в контроле) достоверно (p < 0,001) увеличивалась по фазам вегетации, особенно в вариантах, где гидрогель применяли совместно с азот- 

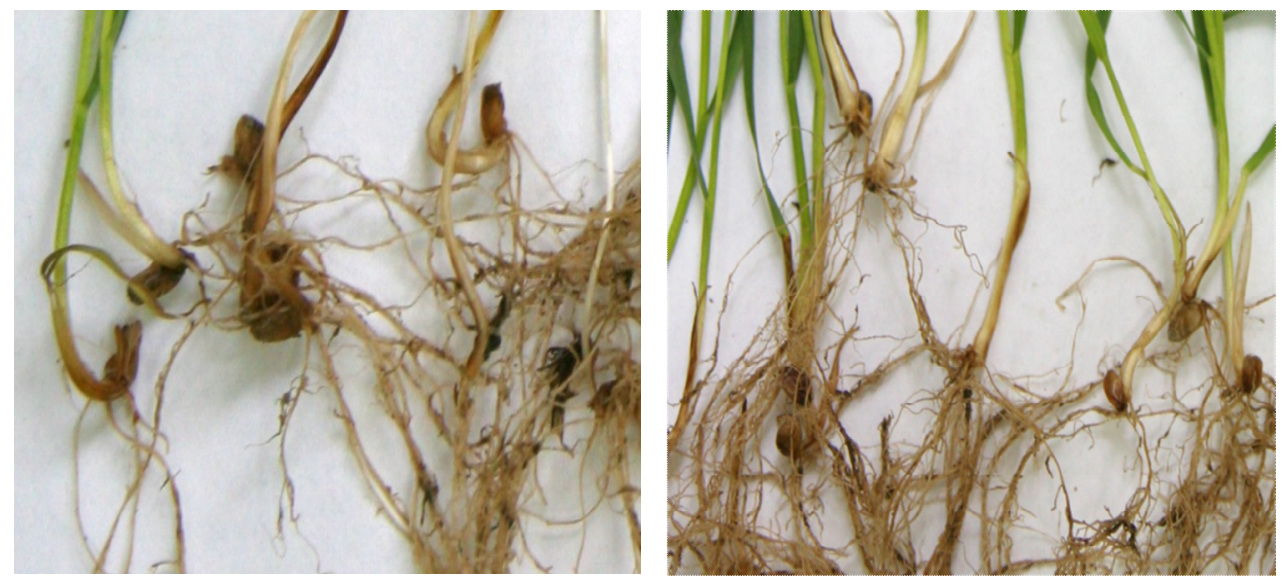

Рис. 1. Развитие корневой системы у яровой пшеницы (Triticum aestivum L.) сорта Эстер в фазу кущения без применения гидрогеля (слева) и при предпосевном внесении гидрогеля Ритин-10 (Россия) (справа) (полевой эксперимент, стационар Меньковского филиала Агрофизического института, Ленинградская обл., 2011 год).

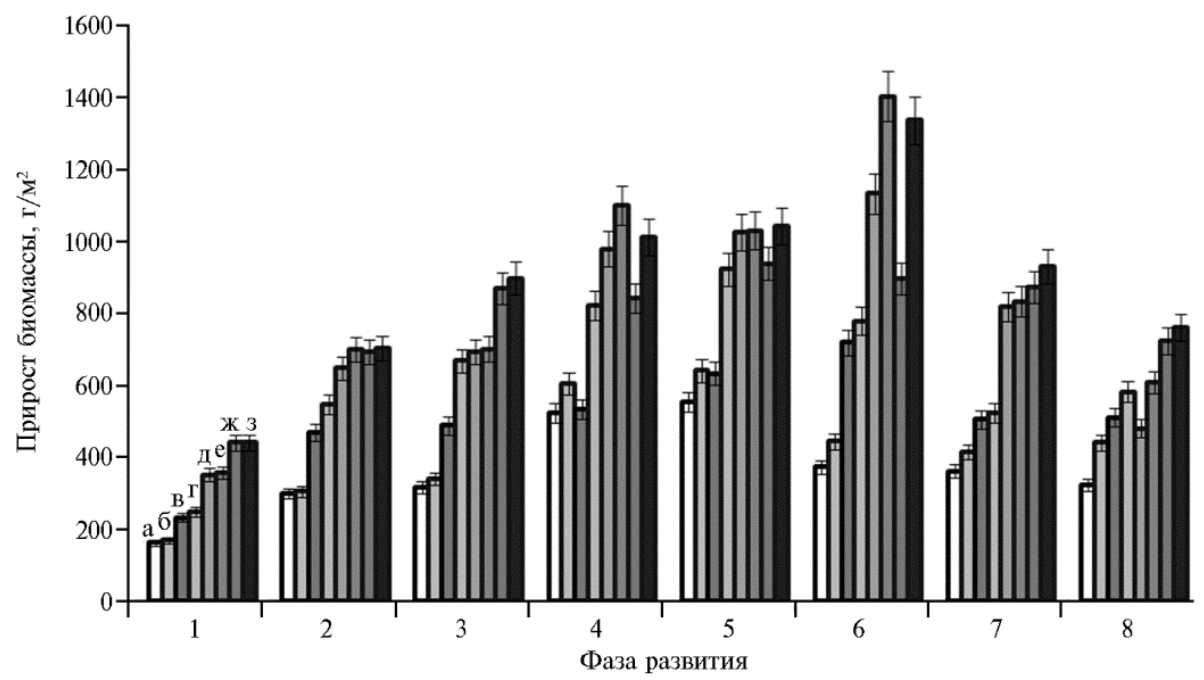

Рис. 2. Динамика накопления биомассы у яровой пшеницы (Triticum aestivum L.) сорта Эстер под влиянием гидрогеля Ритин-10 (Россия, 400 кг/га) и азотных удобрений: а - контроль 1, б контроль 2 (контроль $1+$ гель); в $-\mathrm{N}_{60}$, г $-\mathrm{N}_{60}+$ гель; д $-\mathrm{N}_{90}$; е $-\mathrm{N}_{90}+$ гель; ж $\mathrm{N}_{120}$, 3 - $\mathrm{N}_{120}+$ гель; 1 - кущение; 2 - выход в трубку; 3 - колошение; 4 - цветение; 5 цветение-налив; 6 - молочная спелость; 7 - восковая спелость; 8 - полная спелость. Приведены средние $(M)$ и стандартные отклонения $( \pm \mathrm{SD})$ (полевой эксперимент, стационар Меньковского филиала Агрофизического института, Ленинградская обл., 2011 год).

Как известно (21-23), если вода доступна в необходимых количествах, то значительная доля энергии, выделяющейся на поверхности активно развивающихся растений, затрачивается на транспирацию. На интенсивность испарения влияет большое количество факторов (температура испаряющей поверхности, влажность почвы, относительная влажность воздуха, коэффициенты диффузии и турбулентного перемешивания воздуха). Основная часть поглощенной воды, проходя через растение, транспортирует минеральные вещества и испаряется через устьица листьев в атмосферу. При недостатке влаги происходит снижение транспирации вследствие закрытия устьиц, что приводит к завяданию растений. Гидрогель (23-25) наиболее эффективен в стрессовых для роста и развития рас- 
тений условиях (повышенная температура, дефицит влаги в почве). Наши результаты анализа влажности почвы в разные периоды вегетации свидетельствуют, что гидрогель достоверно (p < 0,05) повышал этот показатель по сравнению с контролем. Содержание влаги в вариантах, когда азотные удобрения применялись в сочетании с гидрогелем, варьировало от 19,33 до $31,60 \%$, в присутствии азотных удобрений без гидрогеля - от 13,14 до $17,40 \%$. В контроле без гидрогеля влажность почвы в период вегетации находилась в пределах от 11,36 до 17,10\%. Следовательно, влаги, удержанной гидрогелем, оказалось достаточно для использования на транспирацию, что положительно влияло на рост, развитие и продуктивность растений. Особенно важно наличие минимального запаса почвенной влаги на начальных этапах развития растений пшеницы. Внесение гидрогеля способствует улучшению условий прорастания семян и питания растений в ходе формирования климатически обеспеченного урожая $(25,26)$.

Aquasorb - суперабсорбент на основе анионного полиакриламида, представляет собой нерастворимый в воде сшитый сополимер акриламида и акрилата калия. Абсорбент слабо подвержен биодеградадии, не гидролизует-

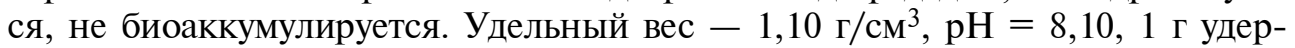
живает около 400 мл воды; адсорбция в деионизированной воде - 400 г/г, в почве -150 г/г, влагоудержание при рF $1-980$ мл/л, возврат воды (около точки высыхания) - $95 \%$, ёмкость катионного обмена - 4,6 мэкв/г. Производительность в почве - до 5 лет (26). Суперабсорбент Aquasorb широко применяется в растениеводстве, лесоводстве и садоводстве (для перевозки и при посадке саженцев), цветоводстве, овощеводстве (в теплицах), бахчеводстве, животноводстве (в подстилках для животных), ландшафтном дизайне (альпийские горки, газоны).

В стационарных опытах в условиях Казахского НИИ земледелия и растениеводства плотность светло-каштановой легкосуглинистой почвы

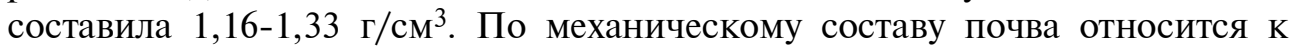
легким суглинкам, содержание физической глины 39-42 \%, крупной пыли $-45-50 \%$, ила - 12-17\%. Содержание карбонатов в верхних слоях составляет 2,7-3,6 \%, в карбонатном горизонте - 6,5 \%. Сумма поглощенных оснований не превышает 12 мг-экв на 100 г почвы. На долю кальция приходится 80-90 \%, магния - 10-20\%, количество поглощенного натрия ничтожно. Обеспеченность почвы легкогидролизуемым азотом средняя, подвижным фосфором - низкая, обменным калием - средняя (по Кирсанову - ГОСТ 26207-91), светло-каштановая почва в верхнем горизонте содержит 0,12-0,14 \% валового азота, 2,02 \% гумуса (ГОСТ 26213-91), водорастворимыми солями не засолена (сумма солей в верхнем слое не превышает 0,12\%) (27). Предшественником озимой пшеницы был чистый пар. Перед посевом проводили плоскорезную вспашку культиватором КРН-2-150 («Тюменьмаш», Россия) на глубину 20-22 см.

Исследования, выполненные в условиях Казахстана, показали, что применение Aquasorb на посевах озимой пшеницы эффективно увеличивает запасы влаги, особенно при выращивании без орошения (28). Было обнаружено, что в период кущения озимой пшеницы запасы продуктивной влаги в почвенном слое глубиной 1 м при внесении Aquasorb в дозах 20 и 40 кг/га были выше на 13-19 мм (или 10,3-19,0 \%) по сравнению с контрольным фоном (без Aquasorb). При применении азотной подкормки в дозе $\mathrm{N}_{45}$ с гидрогелем, запасы продуктивной влаги составили 30-39 мм (или на 23,9-31,0 \% выше, чем в контроле). Самые большие запасы продуктивной влаги при выращивании озимой пшеницы наблюдали при внесении Aquasorb (40 кг/га) с азотной подкормкой в дозе $\mathrm{N}_{45}$, наименьшие - 
в варианте только с азотной подкормкой $\mathrm{N}_{45}$, запасы влаги были только на 6 мм $(4,8 \%)$ выше, чем на контроле.

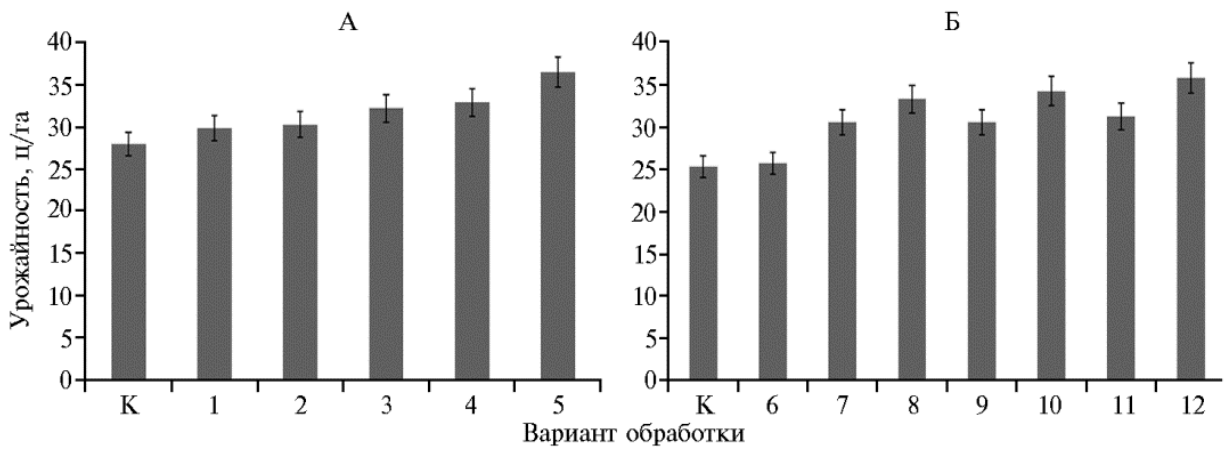

Рис. 3. Урожайность пшеницы (Triticum aestivum L.) при применении гидрогелей и азотных удобрений: А - озимая пшеница (сорт Стекловидная 24, Aquasorb, Казахстан), Б - яровая пшеница (сорт Эстер Ритин-10, Россия); K - контроль (без добавок), 1 - $\mathrm{N}_{45}, 2$ - Aquasorb $20 \mathrm{\kappa г} / г$ га, $3-\mathrm{N}_{45}+$ Aquasorb 20 кг/га, 4 - Aquasorb 40 кг/га, $5-\mathrm{N}_{45}+$ Aquasorb 40 кг/га; 6 - Ритин-10 400 кг/га, $7-\mathrm{N}_{60}, 8-\mathrm{N}_{60}+$ Ритин-10 400 кг/га, $9-\mathrm{N}_{90}, 10-\mathrm{N}_{90}+$ Ритин-10 400 кг/га, $11-\mathrm{N}_{120}, 12-\mathrm{N}_{120}+$ Ритин-10 400 кг/га. Приведены средние $(M)$ и стандартные отклонения $( \pm \mathrm{SD})$. Полевые эксперименты, стационары Казахского НИИ земледелия и растениеводства (2015-2016 годы) и Меньковского филиала Агрофизического института (Ленинградская обл., 2011 год).

При применении Aquasorb без удобрений и в сочетании с удобрением урожайность озимой пшеницы колебалась в пределах 27,00-35,70 ц/га (рис. 3, А). Внесение гидрогеля Aquasorb достоверно (p < 0,05) повысило урожайность зерна, особенно в сочетании с азотными удобрениями. Самый высокий урожай без использования азотных удобрений получили при внесении Aquasorb в дозе 40 кг/га (32,20 ц/га, что на 5,20 ц/га превысило контроль), а сочетание Aquasorb 40 кг/га $+\mathrm{N}_{45}$ дало прибавку 8,70 ц/га по сравнению с контролем. Обработка гидрогелем Ритин-10 привела к достоверному ( $<<0,001)$ росту урожайности зерна яровой пшеницы (см. рис. 3, Б). Этот показатель в вариантах с гидрогелем в сочетании с азотными удобрениями колебался от 33,23 до 35,70 ц/га. Самый высокий урожай получили в варианте $\mathrm{N}_{120}+$ Ритин-10 (урожайность зерна была на 10 ц/га больше, чем в контроле без удобрений и без геля). Прибавка урожая по вариантам составила: для $\mathrm{N}_{60}+$ Ритин-10 - 20,6 \%, для $\mathrm{N}_{90}+$ Ритин-10 $33,0 \%$, для $\mathrm{N}_{120}+$ Ритин-10 - 38,9 \% по сравнению с контролем.

Таким образом, проведенные исследования по оценке влияния гидрогеля Ритин-10 на водообеспеченность посевов пшеницы показали, что при его внесении в предпосевной период улучшается развитие корневой системы в фазу кущения. Выявлено, что гидрогель аккумулирует достаточное количество почвенной влаги для нормального роста и развития растений пшницы в засушливые периоды вегетации, что способствует повышению урожайности культуры. По влиянию на водообеспеченность растений гидрогель Ритин-10 проявляет высокую эффективность в сравнении с суперабсорбентом Aquasorb.

\section{ЛИТЕРАТУРА}

1. Казанский К.С., Агафонов О.А., Усков И.Б., Романов И.А. Сильнонабухающие полимерные гидрогели - новые влагоудерживающие почвенные добавки. Вестник сельскохозяйственной науки, 1988, 4: 125-132.

2. Puoci F., Iemma F., Spizzirri U.G., Cirillo G., Curcio M. Polymer in agriculture: A review. American Journal of Agricultural and Biological Science, 2008, 3: 299-314 (doi: 10.3844/ajabssp.2008.299.314). 
3. Ekebafe L.O., Ogbeifun D.E., Okieimen F.E. Polymer applications in agriculture. Biokemistri, 2011, 23: 81-89.

4. Taban M., Movahedi Naeini S.A.R. Effect of Aquasorb and organic compost amendment on soil water retention and evaporation with different evaporation potentials and soil textures. Communications in Soil Science and Plant Analysis, 2006, 37: 2031-2055 (doi: 10.1080/00103620600770383).

5. Mengold J.M., Sheley R.I. Effects of soil texture, watering frequency on the emergence and survival of wheat grass seeds. Ecological Restoration, 2007, 25(1): 7-11.

6. Liao R., Wu W., Ren S., Yang R. Effects of superabsorbent polymers on the hydraulic parameter and water retention properties of soil. Journal of Nanomaterials, 2016, 2016: Article ID 5403976 (doi: 10.1155/2016/5403976).

7. Годунова Е.И., Гундырин В.Н., Шкабарда С.Н. Перспективы использования гидрогеля в земледелии Центрального Предкавказья. Достижения науки и техники АПК, 2014, 1: 24-27.

8. Данилова Т.Н. Водопоглощающие полимеры для управления водообеспеченностью сельскохозяйственных культур. Известия Санкт-Петербургского аграрного университета, 2018, 3(52): 47-53.

9. Volkamar K.M., Chang C. Influence of hydrophilic gel polymers on water relations, growth and yield of barley and canola. Canadian Journal of Plant Science, 1995, 75(3): 605-611 (doi: $10.4141 /$ cjps95-105).

10. Cheruiyot G., Sirmah P., Ng,etich W., Mengich E. Effects of hydrogels on soil moisture and growth of Cajanus cajan in Semi Arid Zone of Kongelai, West Pokot County. Open Journal of Forestry, 2014, 4(1): 34-37 (doi: 10.4236/ojf.2014.41006).

11. Shahid S.A., Qidwai A.A., Anwar F., Ullah I., Rashid U. Improvement in the water retention characteristics of sandy loam soil using a newly synthesized poly (acrylamide-co-acrylic acid)/ $\mathrm{AIZnFe}_{2} \mathrm{O}_{4}$ superabsorbent hydrogel nanocomposite material. Molecules, 2012, 17(8): 9397-9412 (doi: 10.3390/molecules17089397).

12. Mohammad J., Zohuriaan-Mehr M.J., Kabiri K. Superabsorbent polymer materials: a review. Iranian Polymer Journal, 2008, 17(6): 451-477.

13. Barihi R., Panahpour E., Beni M.H.M. Super absorbent polymer (Hydrogel) and its application in agriculture. World of Sciences Journal, 2013, 1(15): 223-228.

14. Banedjschafie S., Durner W. Water retention properties of a sandy soil with superabsorbent polymers as affected by aging and water quality. Journal of Plant Nutrition and Soil Science, 2015, 178(5): 798-806 (doi: 10.1002/jpln.201500128).

15. Hüttermann A.L., Orikiriza L.J.B., Agaba H. Application of superabsorbent polymers for improving the ecological chemistry of degraded or polluted lands. Clean Soil, Air, Water, 2009, 37(7): 517-526 (doi: 10.1002/clen.200900048).

16. Данилова Т.Н. Влияние полимерного геля РИТИН-10 на водно-физические свойства почв. Агрофизика, 2013, 2: 38-43.

17. Данилова Т.Н., Козырева Л.В. Возможности использования гидрогелей для управления водообеспеченностью полей. Плодородие, 2008, 6: 24-25.

18. Годунова Е.И., Гундырин В.Н. Роль гидрогеля в улучшении влагообеспеченности озимой пшеницы по полупару в зоне неустойчивого увлажнения Ставропольского края. Достижения науки и техники АПК, 2015, 29(5): 57-59.

19. Доспехов Б.А. Методика полевого опыта. М., 1985: 84-88.

20. Вавилов П.П., Гриценко В.В., Кузнецов В.С., Лукьянюк В.И., Третьяков Н.Н., Шатилов И.С. Растениеводство. М., 1986.

21. Yang W., Li P., Guo S., Fan B., Song R., Zhang J., Yu J. Compensating effect of fulvic acid and super-absorbent polymer on leaf gas exchange and water use efficiency of maize under moderate water deficit conditions. Plant Growth Regulation, 2017, 83: 351-360 (doi: 10.1007/s10725017-0297-9).

22. Khadem S.A., Galavi M., Ramrodi M., Mousavi S.R., Rousta M.J. Effect of animal manure and super absorbent polymer on corn leaf relative water content, cell membrane stability and leaf chlorophyll content under dry condition. Australian Journal of Crop Science, 2010, 4(8): 642-647.

23. Montesano F., Parente A., Santamaria P., Sannino A., Serio F. Biodegradable super absorbent hydrogel increases retention properties of growing media and plant growth. Agriculture and Agriculture Science Procedia, 2015, 4: $451-458$ (doi: 10.1016/j.aaspro.2015.03.052).

24. Orikiriza L.J.B., Agaba H., Eilu G., Tweheyo M., Kabasa J.D. Amending soils with hydrogels increases the biomass of nine tree species under non-water stress conditions. Clean Soil Air Water, 2009, 37: 615-620 (doi: 10.1002/clen.200900128).

25. Тибирьков А.П., Филин В.И. Влияние полимерного гидрогеля и условий минерального питания на урожай и качество зерна озимой пшеницы на светло-каштановых почвах. Известия Нижневолжского агроуниверситетского комплекса (НВАУК): наука и высшее профессиональное образование, 2012, 3(27): 2-5. 
26. Li X., He J.-Z., Hughes J.M., Liu Y.-R., Zheng Y.-M. Effects of super-absorbent polymers on a soil-wheat (Triticum aestivum L.) system in the field. Applied Soil Ecology, 2014, 73: 58-63 (doi: 10.1016/j.apsoil.2013.08.005).

27. Данилова Т.Н., Табынбаева Л.К., Кененбаев С.Б., Бойко В.С. Роль абсорбента AQUASORB в улучшении водоудерживающей способности почв. Агрофизика, 2018, 2: 1-8.

28. Tabynbayeva L.K., Kenenbayev S.B., Suleimenova M.S., Tinibayev N.K., Boiko V.S. Impact of absorbing agent on moisture reserves of winter wheat in the conditions of semiprovided dry farming land of the south-east of Kazakhstan. OnLine Journal of Biological Sciences, 2017, 17(2): 35-39 (doi: 10.3844/ojbsci.2017.35.39).

\footnotetext{
1 ФГБНУ Агрофизический научно-исследовательский институт, Поступила в редакцию 195220 Россия, г. Санкт-Петербург, Гражданский просп., 14, e-mail: danilovatn@yandex.ru $\bowtie$;
}

2 ТОО Казахский НИИ земледелия и растениеводства, 040909 Республика Казахстан, Алматинская обл., Карасайский р-н, пос. Алмалыбак, ул. Ерлепесова, 1,

e-mail: tabynbaeva.lyalya@mail.ru

Sel'skokhozyaistvennaya biologiya [Agricultural Biology], 2019, V. 54, № 1, pp. 76-83

\title{
POLYMER GELS TO MANAGE WATER AVAILABILITY FOR WHEAT ( Triticum aestivum L.) UNDER VARIOUS ENVIRONMENT CONDITIONS
}

\author{
T.N. Danilova ${ }^{1}$, L.K. Tabynbayeva ${ }^{2}$
}

${ }^{1}$ Agrophysical Research Institute, 14, Grazhdanskii prosp., St. Petersburg, 195220 Russia, e-mail danilovatn@yandex.ru ( $\triangle$ corresponding author);

${ }^{2}$ LLP Kazakh Scientific Research Institute of Arable Farming and Horticulture, 1, st. Erlepesov, Almaty Province, Karasay Region, Almalybak, 040909 Republic of Kazakhstan, e-mail tabynbaeva.lyalya@mail.ru ORCID:

Danilova T.N. orcid.org/0000-0001-6926-6155

The authors declare no conflict of interests

Received September 28, 2018

Tabynbayeva L.K. orcid.org/0000-0001-9721-6737

doi: 10.15389/agrobiology.2019.1.76eng

\section{Abstract}

During the last years, due to climate changes and reducing water availability for crops, special attention is paid to moisture-swelling polymers. In this paper we compared the influence of Russian hydrogel Ritin-10 (LLC RITEK-ENPTs, Russia) and polymer Aquasorb (SNF s.a.s., France) on spring and winter wheats in Russia and Kazakhstan. The effect of Ritin-10 hydrogel on spring wheat Esther variety water supply was studied in a field experiment (Russia, 2011) with the hydrogel dosage of $400 \mathrm{~kg} / \mathrm{ha}$ and its combination with nitrogen fertilizers $\left(\mathrm{N}_{60}, \mathrm{~N}_{90}\right.$, and $\left.\mathrm{N}_{120}\right)$. Analysis of soil moisture during different periods of vegetation showed that Ritin-10 significantly ( $\mathrm{p}<0.05$ ) increases soil moisture as compared to the control. The moisture content in use of nitrogen fertilizers combined with the hydrogel varied from 19.33 to $31.60 \%$, and in use of nitrogen fertilizers without hydrogel from 13.14 to $17.40 \%$. In the control, the soil moisture during the vegetation period was from 11.36 to $17.10 \%$. Reserves of productive moisture under Aquasorb application on winter wheat Glassy variety 24 crops at tillering (Kazakhstan, 2015-2016) were 10.30-19.00\% higher compared to the control. When using $\mathrm{N}_{45}$, the reserves of productive moisture were $23.90-31.00 \%$. The use of Ritin-10 hydrogel on wheat crops leads to a significant $(p<0.001)$ increase in grain yield. The grain yield of spring wheat under a combined effect of Ritin-10 hydrogel and nitrogen fertilizers varied from 33.23 to $35.7 \mathrm{c} / \mathrm{ha}$. In our tests, the combination $\mathrm{N}_{120}+$ Ritin-10 provided the highest grain yield which exceeded control by $10 \mathrm{c} /$ ha. Aquasorb without fertilizers and with $\mathrm{N}_{45}$ yields grain harvest of 27.0-35.7 c/ha for winter wheat variety Glassy 24 . This study showed that Ritin-10, like superabsorbent polymer Aquasorb, can effectively manage water availability and water supply of crops.

Keywords: Triticum aestivum L.), spring wheat, winter wheat, water-absorbing polymers, soil moisture, root system, water availability, yield.

\section{Научные собрания \\ 7th EDITION OF INTERNATIONAL CONFERENCE ON PHARMACOGNOSY AND MEDICINAL PLANTS}

(March 11-12, 2019, London, United Kingdom)

Subdisciplines: biology, biochemistry, botany, toxicology, biotechnology, complementary medicine, pharmacy \& pharmacology

Information: http://pharmacognosy.euroscicon.com/ 